Rev. Fac. Agron. (LUZ). 2021, 38(4): 1108-1133. Octubre-Diciembre.

DOI: https://doi.org/10.47280/RevFacAgron(LUZ).v38.n4.20

ISSN 2477-9407

\title{
The price elasticity of the demand and revenue increase for some Mexican planting seeds
}

\author{
La elasticidad precio de la demanda e ingresos para \\ algunas semillas mexicanas
}

\section{A elasticidade-preço da demanda e receita para algumas sementes de plantio no México}

\section{Sergio Orozco Cirilo ${ }^{1 *}$, Juan Manuel Vargas Canales ${ }^{1}$, Sergio Ernesto Medina Cuéllar ${ }^{2}$ and Nicasio García Melchor ${ }^{1}$}

\begin{abstract}
${ }^{1}$ Universidad de Guanajuato. México. Campus Celaya Salvatierra. División de Ciencias Sociales y Administrativas. Departamento de Estudios Sociales. Email: (SO) orozcosergio@ugto.mx, (D); (JV) jm.vargas@ugto.mx, (D); (NG) nicasio@ugto.mx, ${ }^{\mathbb{D}}{ }^{2}$ Universidad de Guanajuato. Campus Irapuato-Salamanca, Departamento de Arte y Empresa. Email: se.medina@ugto.mx, (D.
\end{abstract}

\section{Abstract}

The study of the price elasticity of demand (PED) has been and is a current research topic, as it greatly helps the managers of companies to make decisions about the price of their products and the expected repercussions in changing them. The objective of this study was to estimate PED and its impacts on the variation of income (VI) of six planting seed crops from Mexico, such as yellow corn, other corn (except yellow and sweet corn), sorghum, chickpea, pumpkin and cucumber. The data were gathering from the Foreign Agriculture Service (FAS) (1998-2018 period) through the tables provided and published on the Internet (secondary data). In this study, the arc method was applied to calculate PED and $\mathrm{VI}=((\mathrm{Pf} * \mathrm{Qf} * 100) /(\mathrm{Pi} * \mathrm{Qi}))-100$. Five of six the planting seed products have a relatively elastic demand price in most of the years, on the contrary the revenue increase had positive and negative values, without a defined trend. Sorghum planting seed has in some cases elastic demand and in other inelastic demand. It is concluded that there are no clear effects of the PED on the sales revenue of the aforementioned products; an aspect that contradicts the theory of PED and its impact on income.

Key words: Crop seeds, agricultural prices, export products.

Received: 26-05-2021 • Accepted: 10-07-2021.

*Corresponding autor. Email: orozcosergio@ugto.mx 
Rev. Fac. Agron. (LUZ). 2021, 38(4): 1108-1133. Octubre-Diciembre.

Orozco et al.

ISSN 2477-9407

\section{Resumen}

El estudio de la elasticidad precio de la demanda ha sido y es un tema de investigación actual, pues ayuda enormemente a los gestores de las empresas a tomar decisiones sobre el precio de sus productos y las repercusiones esperadas en el cambio de éstas. El objetivo de este estudio fue estimar la EPD y sus impactos en la variación del ingreso (VI) de seis semillas para la siembra de México, como maíz amarillo, otro maíz (excepto maíz amarillo y dulce), sorgo, garbanzos, calabaza y pepino. Los datos se recopilaron del Servicio de Agricultura Extranjera (FAS) (período 1998-2018) a través de las tablas proporcionadas y publicadas en Internet (datos secundarios). En este estudio, el método de arco se aplicó para calcular EPD y VI $=((\mathrm{Pf} * \mathrm{Qf} * 100) /(\mathrm{Pi} * \mathrm{Qi}))-100$. Cinco de seis semillas para la siembra tienen un precio de demanda relativamente elástico en la mayoría de los años, por el contrario, el aumento de los ingresos tuvo valores positivos y negativos, sin una tendencia definida. El Sorgo tuvo en algunos casos una demanda elástica y en otros una demanda inelástica. Se concluye que no hay efectos claros de la EPD en los ingresos por ventas de los productos antes mencionados; aspecto que contradice la teoría EPD y su impacto en el ingreso.

Palabras clave: Semillas de siembra, precios agrícolas, productos de exportación.

\section{Resumo}

O estudo da elasticidade-preço da demanda tem sido e é um tema atual de pesquisa, pois ajuda muito os gestores das empresas na tomada de decisões sobre o preço de seus produtos e as repercussões esperadas em sua mudança. O objetivo deste estudo foi estimar a EPD e seus impactos na variação do rendimento (VI) de seis sementes para plantio no México, como milho amarelo, outro milho (exceto milho amarelo e doce), sorgo, grão de bico, abóbora e pepino. Os dados foram coletados junto ao Foreign Agriculture Service (FAS) (período 1998-2018) por meio de tabelas disponibilizadas e publicadas na Internet (dados secundários). Neste estudo, o método do arco foi aplicado para calcular EPD e VI $=((\mathrm{Pf} * \mathrm{Qf}$ * 100) / (Pi * Qi)) - 100. Cinco das seis sementes para plantio têm um preço de demanda relativamente elástico na maioria dos anos ao contrário, o aumento da renda teve valores positivos e negativos, sem tendência definida. O sorgo teve em alguns casos uma demanda elástica e em outros uma demanda inelástica. Conclui-se que não há efeitos claros da EPD nas receitas de vendas dos referidos produtos; aspecto que contradiz a teoria do EPD e seu impacto na receita.

Palavras-chave: Sementes, preços agrícolas, produtos de exportação. 
Rev. Fac. Agron. (LUZ). 2021, 38(4): 1108-1133. Octubre-Diciembre.

Orozco et al.

ISSN 2477-9407

\section{Introduction}

The commercial relationship between Mexico and the United States of America (USA) has improved more and more over time (Licona and Correa, 2020). Mexican exports of products to the United States totaled US\$ 32.095 million in May, a year-onyear increase of $9 \%$ (De la Fuente, 2014). Seed exports worldwide have experienced continuous growth over the past few years, reaching US\$ 10,543 million in 2012, where the USA is the main importer of seeds with $14 \%$ of the total (De la Fuente, 2014). According to ISF (2018a and 2018b) for 2017, Mexico exported 740 $\mathrm{t}$ of vegetable crop seeds for a value of 17 million US\$ and imported 1852 $\mathrm{t}$ for a value of 323 million US\$. The Asociación Mexicana de Semilleros, AC (AMSAC) indicates that in Mexico more than 300 varieties of seeds are offered for the main crops in 2012 . Corn, sorghum, rice, chili, tomato and tomatillo seeds are produced (CEDRSSA, 2015).

The national seed industry, especially corn and sorghum, is the one that currently mostly satisfies the national market (CEDRSSA, 2015), opening the possibility to export seeds of these crops (Gobierno del estado de Jalisco, 2015). It is important to note that the production of seeds in Mexico is in the hands of private sector, both national and international, that participates with $94 \%$ of the market. Among the strengths of the seed sector are the genetic diversity of the country, the center of origin of various species and the existence of

\section{Introducción}

La relación comercial entre México y los Estados Unidos de América (EE. UU.) ha mejorado cada vez más con el tiempo (Licona y Correa, 2020). Las exportaciones mexicanas de productos a Estados Unidos totalizaron US\$ 32,095 millones en mayo con un aumento interanual del 9 \% (De la Fuente, 2014). Las exportaciones de semillas en todo el mundo han experimentado un crecimiento continuo en los últimos años, alcanzando los US\$ 10.543 millones en 2012, donde EEUU es el principal importador de semillas con el 14\% del total (De la Fuente, 2014). Según ISF (2018a y 2018b) para 2017, México exportó 740 t de semillas para cultivos vegetales por un valor de 17 millones de US\$ e importó 1852 t por un valor de 323 millones de US\$. La Asociación Mexicana de Semilleros, AC (AMSAC) indica que para 2012, en México se ofrecieron más de 300 variedades de semillas para los principales cultivos. Se producen semillas de maíz, sorgo, arroz, chile, tomate y tomatillo (CEDRSSA, 2015).

La industria nacional de semillas, especialmente maíz y sorgo, es la que actualmente satisface mayormente al mercado nacional (CEDRSSA, 2015), abriendo la posibilidad de exportar semillas de estos cultivos (Gobierno del estado de Jalisco, 2015). Es importante destacar que la producción de semillas en México está en manos del sector privado, tanto nacional como internacional, que participa con el $94 \%$ del mercado. Entre las fortalezas del sector productivo de 


\section{Rev. Fac. Agron. (LUZ). 2021, 38(4): 1108-1133. Octubre-Diciembre.}

institutions that are part of the seed market (Mastretta-Yanes et al., 2019). In the case of corn, it is proposed to promote the participation of small corn seed producing companies at local and regional levels (Luna et al., 2012).

The price elasticity of the demand is a measure to quantify the percentage variation in the demanded quantity, with respect to the percentage changes in prices along the demand curve (Samuelson and Nordhaus, 2005; Krugman and Wells, 2006). The study of the price elasticity of demand has been and is a current research topic, as it greatly helps the managers of companies to make decisions about the price of their products and the expected repercussions in changing them (Hernández and García, 2014). More specifically, price elasticity in the seed-planting sector varies significantly depending on multiple factors: land ownership, period of time, seed policies, seed producer profile, etc. (Mora et al., 2014).

The main advantage offered by the calculation of the price elasticity of demand (PED) is that it allows the seed companies to anticipate the behavior of the market in the face of a variation of factors such as the price of goods and services. An increase in the price of a good can increase the price of other goods, it is convenient for seed companies to calculate as accurately as possible how this situation will affect their sales and in this way be able to carry out the necessary adjustments so that this impacts the minimum to the company. semillas, se encuentran la diversidad genética del país, el centro de origen de diversas especies y la existencia de instituciones que forman parte del mercado de semillas (Mastretta-Yanes et al., 2019). En el caso del maíz, se propone promover la participación de pequeñas empresas productoras de semillas de maíz a nivel local y regional (Luna et al., 2012).

La elasticidad precio de la demanda es una medida para cuantificar la variación porcentual en la cantidad demandada, con respecto a los cambios porcentuales en los precios a lo largo de la curva de demanda (Samuelson y Nordhaus, 2005; Krugman y Wells, 2006). El estudio de la elasticidad precio de la demanda ha sido y es un tema de investigación actual, ya que ayuda enormemente a los directivos de las empresas a tomar decisiones sobre el precio de sus productos y las repercusiones esperadas en su cambio (Hernández y García, 2014). Más específicamente, la elasticidad de los precios en el sector de semillas para la siembra varía significativamente dependiendo de múltiples factores: propiedad de la tierra, período de tiempo, políticas de semillas, perfil del productor de semillas, entre otros (Mora et al., 2014).

La principal ventaja que ofrece el cálculo de la elasticidad precio de la demanda (PED) es que permite a las empresas de semillas anticiparse al comportamiento del mercado frente a una variación de factores como el precio de los bienes y servicios. Un aumento en el precio de un bien puede aumentar el precio de otros bienes, es conveniente que 
Rev. Fac. Agron. (LUZ). 2021, 38(4): 1108-1133. Octubre-Diciembre.

Orozco et al.

ISSN 2477-9407

If the elasticity is less than 1.0, it is inelastic, while demand is elastic when it is greater than -1.0 (Herrera, 2013; Suárez, 2017). Referentially, in Herrera's approach the price point elasticity is determined by a differential calculation, which yields also negative values. This is due to the inverse relationship between price and demand. In the case when the PED tends to minus infinity, it is perfectly elastic; however, the original focus widely used in the scope of PED is that of Samuelson and Norhdaus (2005), and Krugman and Wells (2006). In both approaches, they use the absolute values, excluding negative values. This is the methodology used in this work.

The main purpose of this research is to validate the evolutionary impact price elasticity of demand on the net income of various seed of Mexican crops seeds, during the period 1998-2018. For this, the price elasticity of the demand and net income of corn (Zea mays L.), sorghum (Sorghum bicolor (L.) Moench), chickpea (Cicer arietinum L.), pumpkin (Cucurbita maxima L.) and cucumber seeds (Cucumis sativus L.) were estimated in the period under consideration.

\section{Materials and methods}

This research is a correlationalevolutive type investigation, since we have obtained the relations and correlations between prices and incomes for each PED detected in a period of 20 years. las empresas de semillas calculen con la mayor precisión posible cómo esta situación afectará sus ventas y de esta manera poder realizar los ajustes necesarios para que esto impacte minimamente a la empresa.

Si la elasticidad es menor que 1,0 , esta es inelástica, mientras que la demanda es elástica cuando es mayor que -1,0 (Herrera, 2013; Suárez, 2017). Referencialmente, en el enfoque de Herrera (2013) la elasticidad de cada punto de precio está determinada por un cálculo diferencial, que también produce valores negativos. Esto se debe a la relación inversa entre precio y demanda. En el caso de que el EPD tienda a menos infinito, es perfectamente elástico; sin embargo, el enfoque original ampliamente utilizado en el alcance de la EPD, es el de Samuelson y Norhdaus (2005), y Krugman y Wells (2006). En ambos enfoques, se utilizan los valores absolutos, excluyendo los valores negativos. Esta es la metodología utilizada en este trabajo.

El objetivo principal de esta investigación es validar el impacto evolutivo de la elasticidad precio de la demanda sobre el ingreso neto de diversas semillas de cultivos mexicanos, durante el período 1998-2018. Para ello, en el período considerado, se estimó la elasticidad precio de la demanda y los ingresos netos de las semillas de maíz (Zea mays L.), sorgo (Sorghum bicolor (L.) Moench), garbanzo (Cicer arietinum L.), calabaza (Cucurbita 


\section{Rev. Fac. Agron. (LUZ). 2021, 38(4): 1108-1133. Octubre-Diciembre.}

\section{Orozco et al.}

ISSN 2477-9407

\section{Obtaining and analyzing data}

To calculate the price elasticity of the demand and revenue increase of yellow corn, other corns, sorghum, chickpea, pumpkin and cucumber, it was necessary to get the data of exports in dollars and volume in metric tons of these six planting seeds. These data were obtained from the Foreign Agriculture Service (FAS, 2019) of the United States Department of Agriculture (USDA) for the 1998-2018 period through the tables it provided and published on Internet (Secondary data). Using the information, the elasticity matrix was constructed, which will be utilized in the analysis. This elasticity matrix is created based on the reference export price in dollars for each $t$. and the volume exported in t.

It is indicated, that exports expressed in millions of dollars, will be considered as the overall average price, by which these planting seeds were acquired, since the price at which the planting seeds of export are negotiated and attained, it is used to analyze in quantitative terms how the market of a certain product adapts or adjusts to variations in the price of the same accounted for in millions of dollars, besides these prices vary according to a change in the real exchange rate and the record of tons of export will be equal to the average annual quantity demanded of these planting seeds. Based on this, the estimations were determined according to the formula of the price elasticity of the demand for a product. The price elasticity of demand can be estimated using the arc method as follows: maxima L.) y pepino (Cucumis sativus L.).

\section{Materiales y métodos}

Esta investigación es de tipo correlacional-evolutiva, ya que se han obtenido las relaciones y correlaciones entre precios e ingresos para cada PED detectado en un período de 20 años.

Obtención y análisis de datos

Para calcular la elasticidad precio de la demanda y el aumento de ingresos del maíz amarillo, otros maíces, sorgo, garbanzo, calabaza y pepino, fue necesario obtener los datos de exportaciones en dólares y volumen en toneladas métricas de estas seis semillas de cultivo. Estos datos fueron obtenidos del Foreign Agriculture Service (FAS, 2019) del Departamento de Agricultura de Estados Unidos (USDA) para el período 1998-2018 por medio de los cuadros que se publicaron en Internet (datos secundarios). Con la información se construyó la matriz de elasticidad, que será utilizada en el análisis. Esta matriz de elasticidad se crea con base en el precio de exportación de referencia en dólares por cada t y el volumen exportado en $t$.

Las exportaciones expresadas en millones de dólares, serán consideradas como el precio promedio global por el cual se adquirieron estas semillas de cultivo ya que, el precio al que se negocian y alcanzan las semillas de exportación se utiliza para analizar en términos cuantitativos cómo el mercado de un determinado producto se adapta o ajusta a variaciones en el precio del 
Rev. Fac. Agron. (LUZ). 2021, 38(4): 1108-1133. Octubre-Diciembre.

Orozco et al.

ISSN 2477-9407

$E_{d}=\frac{\ddot{A} \% Q}{\ddot{A} \% P}$

and,

$$
\mathrm{E}_{\mathrm{d}}=\frac{\frac{\Delta \mathrm{Q}}{\mathrm{Q}_{1}}}{\frac{\Delta \mathrm{P}}{\mathrm{P}_{1}}}=\frac{\mathrm{P}_{1}}{\mathrm{Q}_{1}} \times \frac{\Delta \mathrm{Q}}{\Delta \mathrm{P}}=\left(\frac{\mathrm{P}_{1}}{\mathrm{Q}_{1}}\right) \times\left(\frac{\mathrm{Q}_{2}-\mathrm{Q}_{1}}{\mathrm{P}_{2}-\mathrm{P}_{1}}\right)
$$

where: $\mathrm{P}_{1}=$ Initial price, $\mathrm{P}_{2}=$ Final price, $\mathrm{Q}_{1}=$ Initial quantity and $\mathrm{Q}_{2}=$ Final quantity

It must be pointed out, that to apply the above equation, it is necessary to know the quantities demanded at the different prices, but all the other factors that influence the consumers demand remain constant (ceteris paribus or remaining the rest constant), (Samuelson and Nordhaus, 2005; MasterIT.ie., 2006; Miller and Meiners, 1990).

Total income (TI) can be defined as the unit price multiplied by the quantity demanded, since this is the quantity of income received by any seller in a product, who charges a unit price equal to $\mathrm{P}$, multiplied by the total of units sold, $\mathrm{Q}$. ( $\mathrm{TI}=\mathrm{P}$ * Q) (Samuelson and Nordhaus, 2005; Miller and Meiners, 1990).

The revenue increase (RI) can be calculated in both initial and final state, using the equation of the total income formula as follow (Omni Calculator, 2019):

$$
R I=\frac{\left(P_{2} \cdot Q_{2} \cdot 100\right)}{P_{1} \cdot Q_{1}}-100
$$

where: $\mathrm{P}_{2}, \mathrm{P}_{1} \mathrm{Q}_{2}$ and $\mathrm{Q}_{1}$ as above. The data of exports and volume mismo, contabilizado en millones de dólares, además estos precios varían de acuerdo a un cambio en el tipo de cambio real y el récord de toneladas de exportación será igual a la cantidad promedio anual demandada de estas semillas de cultivo. Con base en esto, las estimaciones se determinaron de acuerdo con la fórmula de la elasticidad precio de la demanda de un producto. La elasticidad precio de la demanda se puede estimar utilizando el método del arco, de la siguiente manera:

$$
\begin{aligned}
& \mathrm{E}_{\mathrm{d}}=\frac{\ddot{\mathrm{A}} \% \mathrm{Q}}{\ddot{\mathrm{A}} \% \mathrm{P}} \\
& \mathrm{y}, \\
& \mathrm{E}_{\mathrm{d}}=\frac{\frac{\Delta \mathrm{Q}}{\mathrm{Q}_{1}}}{\frac{\Delta \mathrm{P}}{\mathrm{P}_{1}}}=\frac{\mathrm{P}_{1}}{\mathrm{Q}_{1}} \times \frac{\Delta \mathrm{Q}}{\Delta \mathrm{P}}=\left(\frac{\mathrm{P}_{1}}{\mathrm{Q}_{1}}\right) \times\left(\frac{\mathrm{Q}_{2}-\mathrm{Q}_{1}}{\mathrm{P}_{2}-\mathrm{P}_{1}}\right)
\end{aligned}
$$

donde:

$\mathrm{P}_{1}=$ Precio inicial, $\mathrm{P}_{2}=$ Precio final, $\mathrm{Q}_{1}=$ Cantidad inicial and $\mathrm{Q}_{2}=$ Cantidad final

Cabe señalar, que para aplicar la ecuación anterior es necesario conocer las cantidades demandadas a los diferentes precios, pero todos los demás factores que influyen en la demanda de los consumidores se mantienen constantes (ceteris paribus o manteniéndo el resto constante), (Samuelson and Nordhaus, 2005; MasterIT.ie., 2006; Miller and Meiners, 1990).

El ingreso total(IT) se puede definir como el precio unitario multiplicado por la cantidad demandada, ya que esta es la cantidad de ingreso que recibe cualquier vendedor de un 


\section{Rev. Fac. Agron. (LUZ). 2021, 38(4): 1108-1133. Octubre-Diciembre.}

\section{Orozco et al.}

of the six planting seeds were introduced in the Excel software for processing, analyzing and to calculate the price elasticity of the demand and revenue increase, both parameters were estimated using the on line calculators: MasterIT.ie. (2006) and Omni Calculator (2019), respectively. As was mentioned earlier, these on-line calculators are based on formulae 1.3, and consist in multiplying the price by the quantity of the final period times 100. Then, the obtained value is divided, by the product of the price by the quantity of the initial period. Finally, this result is subtracted by 100. This procedure was employed by Samuelson and Nordhaus (2005). Once the PED and incomes were calculated for each year, we proceed to compare the results with respect to Table 1. Finally, our results are discussed. producto, que cobra un precio unitario igual a $\mathrm{P}$, multiplicado por el total de unidades vendidas, $\mathrm{Q}$. $(\mathrm{TI}=\mathrm{P}$ * Q) (Samuelson and Nordhaus, 2005; Miller and Meiners, 1990).

El aumento de los ingresos (RI) se puede calcular tanto en el estado inicial como en el final, utilizando la ecuación de la fórmula de ingresos totales de la siguiente manera (Omni Calculator, 2019):

$$
\mathrm{RI}=\frac{\left(\mathrm{P}_{2} \cdot \mathrm{Q}_{2} \cdot 100\right)}{\mathrm{P}_{1} \cdot \mathrm{Q}_{1}}-100
$$

donde: $\mathrm{P}_{2}, \mathrm{P}_{1} \mathrm{Q}_{2}$ and $\mathrm{Q}_{1}$ ya se definieron anteriormente.

Los datos de exportaciones y volumen de las seis semillas de siembra se introdujeron en el software Excel para procesar, analizar y calcular la elasticidad precio de la demanda y el aumento de ingresos,

\section{Table 1. Summary of the fundamental concepts used in this work.}

\section{Cuadro 1. Resumen de los conceptos fundamentales utilizados en este trabajo.}

\begin{tabular}{cccc}
\hline $\begin{array}{c}\text { Elasticity of the } \\
\text { demand }\end{array}$ & Description & Definition & Influence on incomes \\
\hline Greater than 1 $\left(\mathrm{E}_{\mathrm{D}}>1\right)$ & Elastic demand & $\begin{array}{c}\text { Percentage variation of } \\
\text { demanded quantity greater } \\
\text { than percentage price variation }\end{array}$ & $\begin{array}{c}\text { Incomes increase when } \\
\text { price decreases }\end{array}$ \\
Equal to 1 $\left(\mathrm{E}_{\mathrm{D}}=1\right)$ & $\begin{array}{c}\text { Unitary Elastic } \\
\text { demand }\end{array}$ & $\begin{array}{c}\text { Percentage variation of } \\
\text { demanded quantity equal to } \\
\text { percentage price variation } \\
\text { Less than 1 }\left(\mathrm{E}_{\mathrm{D}}<1\right)\end{array}$ & $\begin{array}{c}\text { Incomes do not vary } \\
\text { when price decreases }\end{array}$ \\
Inelastic demand & $\begin{array}{c}\text { Pemanded variation of } \\
\text { percentage price variation }\end{array}$ & $\begin{array}{c}\text { Incomes decrease when } \\
\text { price decreases }\end{array}$ \\
\hline
\end{tabular}

Source: Samuelson and Nordhaus (2005).

Fuente: Samuelson and Nordhaus (2005). 
Rev. Fac. Agron. (LUZ). 2021, 38(4): 1108-1133. Octubre-Diciembre.

Orozco et al.

ISSN 2477-9407

Pearson's correlation coefficients were calculated for the export reference price with the revenue increase and with the exported volume, using years as the common variable. They were calculated for all six Mexican planting seeds. The significance of Pearson's correlation coefficients was determined at $0.01,0.05$, or 0.10 level of probability.

\section{Results and discussion.}

\section{Yellow corn}

The price elasticity of demand for planting seeds of yellow corn varied from 0.07 to 28.76, demand was relatively inelastic in four years, but was relatively elastic in ten years and it was unity elasticity in four years (Table 1). It can be said that the price elasticity of demand was mostly elastic. Table 2 shows the revenue increase, it was negative in 11 years and positive in five years. The highest revenue increase was got in the year 2009 (711.69\%) and the lowest in the years 2002 and 2005 $(-100.00 \%)$. Table 2 shows the relation of exported value and export referential price, as it can be seen the exported volume was very variable. The highest exported quantity was achieved in the year $2010(218.1 \mathrm{t})$ and the lowest in the year $2003(5.1 \mathrm{t})$. In the relation to the export referential price, it was highest in the year 2017 (5,714.0 US $\$ / \mathrm{t})$ and the lowest in the year 2004 (258.3 US $\$ / t)$. Also, the export reference price was very variable. The exports were not done in the years 2002 and 2005 to 2007 , but since 2008, the exports were constant and from year 2013 the export reference price was higher than 3,000 US $\$ /$ t. ambos parámetros se estimaron mediante las calculadoras en línea: MasterIT.ie. (2006) y Omni Calculator (2019), respectivamente. Como se mencionó anteriormente, estas calculadoras en línea se basan en la fórmula 1.3, y consisten en multiplicar el precio por la cantidad del período final por 100. Luego, el valor obtenido se divide, por el producto del precio por la cantidad de el período inicial. Finalmente, este resultado se resta por 100. Este procedimiento fue empleado por Samuelson y Nordhaus (2005). Una vez calculados las EPD y los ingresos para cada año, se procede a comparar los resultados con respecto a la Cuadro 1. Finalmente, se discuten los resultados.

Los coeficientes de correlación de Pearson se calcularon para el precio de referencia de exportación con el aumento de los ingresos y con el volumen exportado, utilizando los años como variable común. Estos, fueron calculados para las seis semillas de cultivo mexicanas. La significancia de los coeficientes de correlación de Pearson se determinó para un nivel de probabilidad de 0,$01 ; 0,05$ ó 0.10 .

\section{Resultados y discusión}

\section{Maíz}

La elasticidad precio de la demanda para sembrar semillas de maíz a marillo varió de 0,07 a 28,76 , la demanda fue relativamente inelástica en cuatro años, pero fue relativamente elástica en diez años y fue elasticidad unitaria en cuatro años (Cuadro 2). Se puede decir que la elasticidad precio de la demanda fue mayoritariamente 
Rev. Fac. Agron. (LUZ). 2021, 38(4): 1108-1133. Octubre-Diciembre.

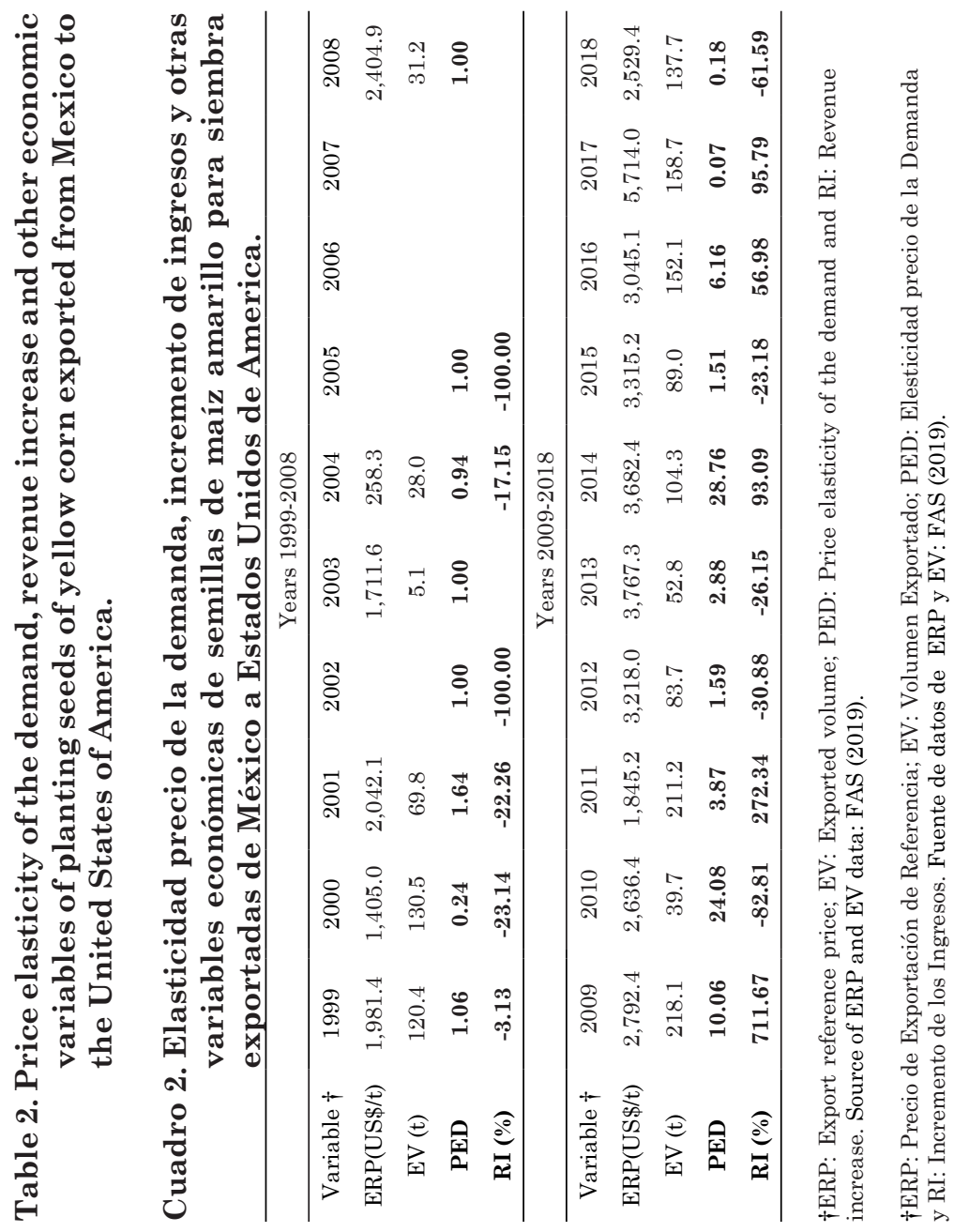


Rev. Fac. Agron. (LUZ). 2021, 38(4): 1108-1133. Octubre-Diciembre.

Orozco et al.

ISSN 2477-9407

Planting seeds of corn (except yellow and sweet corns seeds) had a fluctuating demand, since it varied from 0.07 (the year 2004) to 54.93 (the year 2001). There were eight inelastic demands and 12 elastic demands. This means that there was not a trend in the elasticity, even two inelastic demands were above 1.0 only for 0.07 . In relation to revenue increase, it was negative in ten years and positive in ten years. The highest revenue increase was $1,946.16 \%$ in the year 2012 and the lowest $-90.07 \%$ in the year 2011 (Table 2).

Table 3, displays the relation of exported value and export reference price, as it can be seen, the export volume, was highest in the year 2012 with $1,017.9$ t. (the only case when exported volume overcame 1,000 t) and the lowest occurred in the year 2000 with only $59.0 \mathrm{t}$, but the exported quantity of the product was very irregular through the years. In relation to the export reference price was highest during 2012 with 6,153.3 US $\$ / t$ and lowest during 2006 with only $580.3 \mathrm{US} \$ / \mathrm{t}$. Also, the export reference price was very irregular over the years.

\section{Sorghum}

The price elasticity of demand for planting seeds of sorghum was elastic for six years, inelastic in three years, and unit one in four years. These results showed an irregular trend of elasticity, although it was mostly elastic. The highest elasticity was got in the year 2000 with only 3.54 and the lowest in the year 2012 with 0.44 . The elasticity cannot be estimated in seven years due to there was no export volume in these years. On the other hand, there were five years where the elástica. La Cuadro 2 también muestra el aumento de ingresos, el cual fue negativo en 11 años y positivo en cinco años. El mayor aumento de ingresos se obtuvo en el año 2009 (711,69\%) y el menor en los años 2002 y $2005(-100,00 \%)$.

En la Cuadro 2, se muestra la relación del valor exportado y el precio referencial de exportación, donde se puede apreciar que el volumen exportado fue muy variable. La mayor cantidad exportada se alcanzó en el año $2010(218,1$ t) y la menor en el año 2003 (5,1 t). En relación al precio referencial de exportación, fue más alto en el año 2017 (5.714,0 US \$ / t) y el más bajo en el año 2004 (258,3 US $\$ / \mathrm{t}$ ). Además, el precio de referencia de exportación fue muy variable. Las exportaciones no se realizaron en los años 2002 y 2005 a 2007, pero desde 2008, las exportaciones fueron constantes y desde el año 2013 el precio de referencia de exportación fue superior a 3.000 US $\$ / \mathrm{t}$.

Las semillas de maiz para cultivo (excepto las semillas de maíz amarillo y dulce) tuvieron una demanda fluctuante, ya que varió de 0,07 (el año 2004) a 54,93 (el año 2001). Se presentan ocho demandas inelásticas y 12 demandas elásticas. Esto significa que no hubo una tendencia en la elasticidad, incluso dos demandas inelásticas estuvieron por encima de 1,0 solo para 0,07. En relación al aumento de los ingresos, fue negativo en diez años y positivo en diez años. El mayor aumento de ingresos fue de $1.946,16 \%$ en el año 2012 y el más bajo -90,07\% en el año 2011 (Cuadro 2). 
Rev. Fac. Agron. (LUZ). 2021, 38(4): 1108-1133. Octubre-Diciembre.

\section{Orozco et al.}

ISSN 2477-9407

revenue increase was negative and six years where revenue increase was positive. The highest revenue increase was obtained in the year 2011 with $1,251.80 \%$ and the lowest in the years 1999 and 2002 with $-100.00 \%$.

Table 4 shows the relation of exported value and export reference price, as it can be seen the export reference price was highest in the year $2010(7,169.6 \mathrm{US} \$ / \mathrm{t})$ and lowest in the year 2016 (429. $5 \mathrm{US} \$ / \mathrm{t})$. In relation to exported volume, it was highest in the year 2015 (263.1 t) and lowest in the year $2018(0.4 \mathrm{t})$, also the exported volume was under $1 \mathrm{t}$ in year $2010(0.9 \mathrm{t})$.
En la Cuadro 3, se muestra la relación de valor exportado y precio de referencia de exportación para otros maíces (excepto maíz amarillo y dulce). Como se puede apreciar, el volumen de exportación, fue mayor en el año 2012 con 1.017,9 t, el único caso en el que el volumen exportado superó las 1.000 t y el menor ocurrió en el año 2000 con sólo 59.0 t, pero la cantidad exportada del producto fue muy irregular a lo largo de los años. En relación a la exportación, el precio de referencia fue más alto durante 2012 con $6.153,3$ US \$ / t y más bajo durante 2006 con solo 580,3 US \$ / t. Además, el precio de referencia de

Table 3. Price elasticity of the demand, revenue increase and other economic variables of planting seeds of corn (except yellow and sweet corns) from Mexico to the United States of America.

Cuadro 3. Elasticidad precio de la demanda, aumento de los ingresos y otras variables económicas de las semillas de maíz para cultivo (excepto maíz amarillo y dulce) desde México hacia los Estados Unidos de América.

\begin{tabular}{|c|c|c|c|c|c|c|c|c|c|c|}
\hline \multirow[b]{2}{*}{ Variable $\dagger$} & \multicolumn{10}{|c|}{ Years 1999-2008 } \\
\hline & 1999 & 2000 & 2001 & 2002 & 2003 & 2004 & 2005 & 2006 & 2007 & 2008 \\
\hline $\mathrm{ERP}(\mathrm{US} \$ / \mathrm{t})$ & $1,360.1$ & $1,267.4$ & $1,263.8$ & 812.2 & 834.2 & 587.2 & 796.2 & 580.3 & $1,313.3$ & $1,992.9$ \\
\hline $\mathrm{EV}(\mathrm{t})$ & 430.4 & 59.0 & 69.0 & 156.9 & 101.4 & 99.0 & 71.1 & 177.8 & 223.4 & 322.4 \\
\hline PED & 2.09 & 21.51 & 54.93 & 1.79 & 16.08 & 0.07 & 1.09 & 2.73 & 0.29 & 0.88 \\
\hline \multirow[t]{2}{*}{ RI (\%) } & 54.25 & -87.23 & 16.62 & 46.14 & -33.62 & -31.28 & -2.62 & 82.26 & 184.36 & 118.99 \\
\hline & \multicolumn{10}{|c|}{ Years 2009-2018 } \\
\hline Variable $†$ & 2009 & 2010 & 2011 & 2012 & 2013 & 2014 & 2015 & 2016 & 2017 & 2018 \\
\hline $\operatorname{ERP}(\mathrm{US} \$ / \mathrm{t})$ & $3,122.9$ & $4,734.8$ & $4,222.1$ & $6,153.2$ & $5,767.1$ & $2,439.8$ & $1,452.2$ & 753.2 & $1,030.3$ & $1,869.8$ \\
\hline $\mathrm{EV}(\mathrm{t})$ & 446.4 & 650.8 & 72.5 & $1,017.9$ & 403.2 & 846.5 & 497.0 & 675.6 & 808.8 & 253.1 \\
\hline PED & 0.73 & 0.91 & 13.97 & 4.66 & 13.35 & 0.87 & 1.03 & 0.48 & 0.58 & 1.81 \\
\hline RI (\%) & 116.97 & 121.04 & -90.07 & $1,946.16$ & -62.87 & -11.18 & -65.05 & -29.50 & 63.76 & -43.21 \\
\hline
\end{tabular}

$\dagger$ †RP: Export reference price; EV: Exported volume; PED: Price elasticity of the demand and RI: Revenue increase. Source of ERP and EV data: FAS (2019).

$\dagger$ ERP: Precio de Exportación de Referencia; EV: Volumen Exportado; PED: Elesticidad precio de la Demanda y RI: Incremento de los Ingresos. Fuente de datos de ERP y EV: FAS (2019). 
Rev. Fac. Agron. (LUZ). 2021, 38(4): 1108-1133. Octubre-Diciembre.

Orozco et al.

ISSN 2477-9407

Table 4. Price elasticity of the demand, revenue increase and other economic variables of planting seeds of sorghum exported from Mexico to the United States of America.

Cuadro 4. Elasticidad precio de la demanda, aumento de ingresos y otras variables económicas de las semillas del cultivo de sorgo exportadas de México a Estados Unidos de América.

\begin{tabular}{|c|c|c|c|c|c|c|c|c|c|c|}
\hline & \multicolumn{10}{|c|}{ Years 1999-2008 } \\
\hline Variable $\dagger$ & 1999 & 2000 & 2001 & 2002 & 2003 & 2004 & 2005 & 2006 & 2007 & 2008 \\
\hline ERP(US\$/t) & & $1,000.0$ & 600.1 & & & & & & & \\
\hline $\mathrm{EV}(\mathrm{t})$ & & 3.0 & 48.5 & & & & & & & \\
\hline PED & 1.00 & 1.00 & 3.54 & 1.00 & & & & & & \\
\hline \multirow[t]{2}{*}{ RI (\%) } & -100.00 & & 870.16 & -100.00 & & & & & & \\
\hline & \multicolumn{10}{|c|}{ Years 2009-2018 } \\
\hline Variable $\dagger$ & 2009 & 2010 & 2011 & 2012 & 2013 & 2014 & 2015 & 2016 & 2017 & 2018 \\
\hline $\operatorname{ERP}(\mathrm{US} \$ / \mathrm{t})$ & & $7,169.6$ & $1,713.8$ & $2,103.2$ & $1,200.9$ & $1,701.2$ & $1,158.3$ & 429.5 & 927.9 & $5,667.5$ \\
\hline $\mathrm{EV}(\mathrm{t})$ & & 0.9 & 50.9 & 55.7 & 93.5 & 70.9 & 263.1 & 46.7 & 144.6 & 0.4 \\
\hline PED & & 1.00 & 1.57 & 0.44 & 0.93 & 0.80 & 3.03 & 1.52 & 1.39 & 1.38 \\
\hline RI (\%) & & & $1,251.89$ & 34.29 & -4.15 & 7.42 & 152.66 & -93.42 & 568.94 & -98.31 \\
\hline
\end{tabular}

†ERP: Export reference price; EV: Exported volume; PED: Price elasticity of the demand and RI: Revenue increase. Source of ERP and EV data: FAS (2019).

$\dagger$ ERP: Precio de Exportación de Referencia; EV: Volumen Exportado; PED: Elesticidad precio de la Demanda y RI: Incremento de los Ingresos. Fuente de datos de ERP y EV: FAS (2019).

\section{Chickpea}

The price elasticity of demand of planting seeds of chickpea varied from 1.00 to 83.24 , demand was relatively elastic in 17 years, and never was relatively inelastic in the 20 years and it was unity elasticity in two years (2012 and 2014) with the particularity that there was not exported volume in 2012 and 2013 (Table 4). It can be said that the price elasticity of demand was elastic.

Table 5 displays the revenue increase; it was negative in eight years and positive in ten years. The highest revenue increase was attained in the year $2015(3,826.69 \%)$ and the lowest in the year $2012(-100.00 \%)$. Table 5 also shows the relation of exported value and exportación fue muy irregular a lo largo de los años.

\section{Sorgo}

La elasticidad precio de la demanda para semillas de cultivo de sorgo fue elástica durante seis años, inelástica en tres años y unidad uno en cuatro años. Estos resultados mostraron una tendencia irregular de la elasticidad, aunque mayoritariamente elástica. La elasticidad más alta se obtuvo en el año 2000 con solo 3,54 y la más baja en el año 2012 con 0,44. La elasticidad no se puede estimar en siete años debido a que no hubo volumen de exportación en estos años. Por otro lado, hubo cinco años en los que el aumento de ingresos fue negativo y seis años en los que 


\section{Rev. Fac. Agron. (LUZ). 2021, 38(4): 1108-1133. Octubre-Diciembre.}

\section{Orozco et al.}

ISSN 2477-9407

export reference price, as it can be noted the exported volume was variable. The highest exported quantity was got in the year 2007 (253.6t) and the lowest in the year 2011 (1.5 t), also, the exported volume was low in 2014 (3.9 t). In the relation to the export reference price, it was highest in the year $2011(2,283.7$ $\mathrm{US} \$ / \mathrm{t}$ ) and lowest in the year 2003 (604.2 US\$/t). Also, the export reference price was variable. The exports were not done in the years 2012 and 2013. el aumento de ingresos fue positivo. El mayor incremento de ingresos se obtuvo en el año 2011 con $1.251,80 \%$ y el menor en los años 1999 y 2002 con $-100,00 \%$.

En la Cuadro 4, se muestra la relación del valor exportado con el precio de referencia de exportación, como se puede observar, el precio de referencia de exportación fue más alto en el año 2010 (7.169,6 US \$ / t) y más bajo en el año $2016(429,5$

Table 5. Price elasticity of the demand, revenue increase and other economic variables of planting seeds of chickpea exported from Mexico to the United States of America.

Cuadro 5. Elasticidad precio de la demanda, incremento de ingresos y otras variables económicas de la siembra de semillas de garbanzo exportadas de México a Estados Unidos de América.

\begin{tabular}{ccccccccccc}
\hline & \multicolumn{10}{c}{ Years $1999-2008$} \\
\hline Variable $\dagger$ & 1999 & 2000 & 2001 & 2002 & 2003 & 2004 & 2005 & 2006 & 2007 & 2008 \\
ERP(US\$/t) & 699.5 & 708.0 & 660.7 & 662.7 & 604.2 & 848.3 & 994.4 & 822.3 & 747.3 & 808.9 \\
EV (t) & 145.6 & 172.2 & 149.9 & 116.4 & 141.8 & 39.9 & 87.8 & 152.0 & 253.6 & 208.0 \\
PED & $\mathbf{3 . 1 5}$ & $\mathbf{1 3 . 8 6}$ & $\mathbf{2 . 0 0}$ & $\mathbf{8 3 . 2 4}$ & $\mathbf{2 . 1 3}$ & $\mathbf{3 . 3 4}$ & $\mathbf{4 . 7 3}$ & $\mathbf{2 . 8 3}$ & $\mathbf{5 . 2 4}$ & $\mathbf{2 . 5 0}$ \\
RI (\%) & $\mathbf{1 2 . 7 2}$ & $\mathbf{1 9 . 7 1}$ & $\mathbf{- 1 8 . 7 7}$ & $\mathbf{- 2 2 . 1 1}$ & $\mathbf{1 1 . 0 7}$ & $\mathbf{- 6 0 . 4 9}$ & $\mathbf{1 5 7 . 9 5}$ & $\mathbf{4 3 . 1 6}$ & $\mathbf{5 1 . 6 2}$ & $\mathbf{- 1 1 . 2 2}$ \\
\hline & & & & & Years $2009-2018$ & & & \\
\hline Variable $\dagger$ & 2009 & 2010 & 2011 & 2012 & 2013 & 2014 & 2015 & 2016 & 2017 & 2018 \\
ERP(US\$/t) & 900.0 & $1,044.4$ & $2,283.7$ & & & $1,188.2$ & $1,838.0$ & $1,763.6$ & $1,948.8$ & $1,481.9$ \\
EV (t) & 87.8 & 118.9 & 1.5 & & & 3.9 & 99.0 & 135.3 & 236.7 & 131.1 \\
PED & $\mathbf{7 . 6 2}$ & $\mathbf{2 . 0 3}$ & $\mathbf{2 . 6 2}$ & $\mathbf{1 . 0 0}$ & & $\mathbf{1 . 0 0}$ & $\mathbf{4 . 3 0}$ & $\mathbf{7 . 5 0}$ & $\mathbf{5 . 4 6}$ & $\mathbf{2 . 1 1}$ \\
RI (\%) & $\mathbf{- 5 3 . 0 3}$ & $\mathbf{5 7 . 1 5}$ & $\mathbf{- 9 7 . 2 4}$ & $\mathbf{- 1 0 0 . 0 0}$ & & & $\mathbf{3 , 8 2 6 . 6 9}$ & $\mathbf{3 1 . 1 3}$ & $\mathbf{9 3 . 3 2}$ & $\mathbf{- 5 7 . 8 8}$ \\
\hline
\end{tabular}

$\dagger$ †RP: Export reference price; EV: Exported volume; PED: Price elasticity of the demand and RI: Revenue increase. Source of ERP and EV data: FAS (2019).

$\dagger$ ERP: Precio de Exportación de Referencia; EV: Volumen Exportado; PED: Elasticidad precio de la Demanda y RI: Incremento de los Ingresos. Fuente de datos de ERP y EV: FAS (2019).

\section{Pumpkin}

Planting seeds of pumpkin had a shifting demand, since it varied from 0.15 (the year 2007) to 12.65 (the year 2003). There were seven inelastic demands and 13 elastic demands.
US $\$ /$ t) . En relación al volumen exportado, fue mayor en el año 2015 (263.1 t) y menor en el año 2018 (0.4 t), además el volumen exportado estuvo por debajo de $1 \mathrm{t}$ en el año 2010 (0.9 t). 
Rev. Fac. Agron. (LUZ). 2021, 38(4): 1108-1133. Octubre-Diciembre.

Orozco et al.

ISSN 2477-9407

This means that demand was mostly elastic. In relation to revenue increase, it was negative in 11 years and positive in nine years. The highest revenue increases were $318.38 \%$ in the year 2011 and the lowest $-84.94 \%$ in the year 2002 (Table 6).

\section{Garbanzo}

La elasticidad precio de la demanda de las semillas de garbanzo varió de 1,00 a 83,24 , la demanda fue relativamente elástica en 17 años, y nunca fue relativamente inelástica en los 20 años y fue elasticidad

\section{Table 6. Price elasticity of the demand, revenue increase and other economic variables of planting seeds of pumpkin exported from Mexico to the United States of America.}

Cuadro 6. Elasticidad precio de la demanda, aumento de ingresos y otras variables económicas de la siembra de semillas de calabaza exportadas de México a Estados Unidos de América.

\begin{tabular}{ccccccccccc}
\hline & \multicolumn{10}{c}{ Years 1999-2008 } \\
\hline Variable $\dagger$ & 1999 & 2000 & 2001 & 2002 & 2003 & 2004 & 2005 & 2006 & 2007 & 2008 \\
ERP(US $\$$ t $)$ & $3,243.8$ & $3,468.1$ & $2,210.5$ & $1,173.8$ & $1,097.8$ & $1,210.0$ & $1,101.9$ & $1,288.9$ & $2,801.0$ & $6,516.2$ \\
EV (t) & 588.6 & 440.7 & 153.7 & 43.6 & 107.6 & 94.8 & 103.5 & 106.4 & 95.4 & 124.4 \\
PED & $\mathbf{2 . 2 6}$ & $\mathbf{4 . 3 0}$ & $\mathbf{2 . 1 8}$ & $\mathbf{1 . 8 2}$ & $\mathbf{1 2 . 6 5}$ & $\mathbf{1 . 3 0}$ & $\mathbf{0 . 9 4}$ & $\mathbf{0 . 1 8}$ & $\mathbf{0 . 1 5}$ & $\mathbf{0 . 3 3}$ \\
RI (\%) & $\mathbf{1 0 . 1 9}$ & $\mathbf{- 1 9 . 9 5}$ & $\mathbf{- 7 7 . 7 7}$ & $\mathbf{- 8 4 . 9 4}$ & $\mathbf{1 3 0 . 8 1}$ & $\mathbf{- 2 . 8 9}$ & $\mathbf{- 0 . 5 8}$ & $\mathbf{2 0 . 2 5}$ & $\mathbf{9 4 . 8 5}$ & $\mathbf{2 0 3 . 3 6}$ \\
\hline & & & & & Years $2009-2018$ & & & & \\
\hline Variable $\dagger$ & 2009 & 2010 & 2011 & 2012 & 2013 & 2014 & 2015 & 2016 & 2017 & 2018 \\
ERP(US\$/t) & $3,813.7$ & $5,095.3$ & $6,736.8$ & $6,233.1$ & $3,513.9$ & $4,487.7$ & $4,135.3$ & $3,820.6$ & $4,315.8$ & $3,190.1$ \\
EV (t) & 147.4 & 116.8 & 369.6 & 126.4 & 115.0 & 81.1 & 106.6 & 61.7 & 81.0 & 59.2 \\
PED & $\mathbf{0 . 3 2}$ & $\mathbf{0 . 8 1}$ & $\mathbf{3 . 7 5}$ & $\mathbf{1 2 . 6 3}$ & $\mathbf{0 . 1 7}$ & $\mathbf{1 . 4 2}$ & $\mathbf{3 . 3 2}$ & $\mathbf{6 . 7 4}$ & $\mathbf{2 . 2 2}$ & $\mathbf{1 . 0 4}$ \\
RI (\%) & $\mathbf{- 3 0 . 6 5}$ & $\mathbf{5 . 8 7}$ & $\mathbf{3 1 8 . 3 8}$ & $\mathbf{- 6 8 . 3 6}$ & $\mathbf{- 4 8 . 7 1}$ & $\mathbf{- 9 . 9 3}$ & $\mathbf{2 1 . 1 2}$ & $\mathbf{- 4 6 . 5 2}$ & $\mathbf{4 8 . 3 0}$ & $\mathbf{- 4 5 . 9 8}$ \\
\hline
\end{tabular}

†ERP: Export reference price; EV: Exported volume; PED: Price elasticity of the demand and RI: Revenue increase. Source of ERP and EV data: FAS (2019).

†ERP: Precio de Exportación de Referencia; EV: Volumen Exportado; PED: Elesticidad precio de la Demanda y RI: Incremento de los Ingresos. Fuente de datos de ERP y EV: FAS (2019).

Table 6, shows the relation of exported value and export reference price, as it can be observed, the export volume was highest in the year 1999 with 588.6 t (the only case when exported volume overcame $500 \mathrm{t}$ ) and the lowest occurred in the year 2002 with only $43.6 \mathrm{t}$, but the exported quantity of the product was very irregular through the years. In relation to the export reference unitaria en dos años (2012 y 2014), con la particularidad de que no hubo volumen exportado en 2012 y 2013 (Cuadro 4). Se puede afirmar que la elasticidad precio de la demanda fue elástica.

En el Cuadro 5 muestra el aumento de los ingresos; el cual fue negativo en ocho años y positivo en diez años. El mayor incremento de ingresos se alcanzó en el año 2015 (3.826,69\%) y 
Rev. Fac. Agron. (LUZ). 2021, 38(4): 1108-1133. Octubre-Diciembre.

Orozco et al.

ISSN 2477-9407

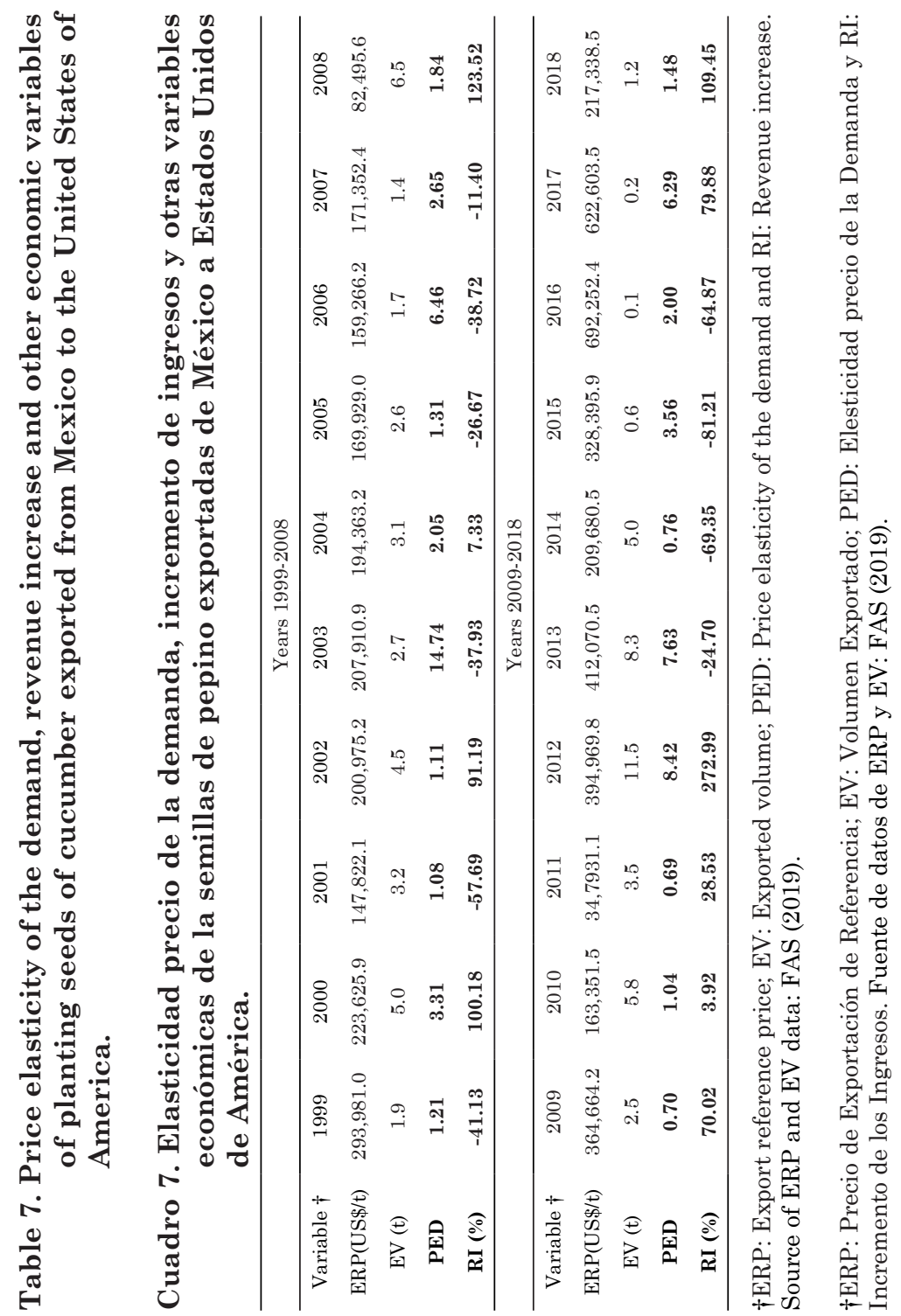


Rev. Fac. Agron. (LUZ). 2021, 38(4): 1108-1133. Octubre-Diciembre.

Orozco et al.

ISSN 2477-9407

price was highest during 2011 with $6,736.8 \mathrm{US} \$ / \mathrm{t}$ and lowest during 2003 with only $1,097.8$ US $\$ /$ t. Also, the export reference price was very irregular through the years but never diminished under 1,000 US $\$ /$ t.

\section{Cucumber}

The price elasticity of demand for planting seeds of cucumber was elastic for 17 years and inelastic in three years. These results showed that the elasticity was mostly elastic. The highest elasticity was got in the year 2003 with 14.74 and the lowest in the year 2011 with 0.69 . In the other hand, there were ten years when the revenue increase was negative and ten years when revenue increase was positive. The highest revenue increase was obtained in the year 2012 with $272.99 \%$ and the lowest in the year 2015 with $-81.21 \%$ (Table 7).

Table 7 displays the relation of exported value and export reference price, as it can be noted the export reference price was highest in the year $2016(692,252.40 \mathrm{US} \$ / \mathrm{t})$ and lowest in the year $1998(66,815.6 \mathrm{US} \$ / \mathrm{t})$. In relation to exported volume, it was highest in the year 1998 (14.2 t) and lowest in the year 2016 (barely $0.1 \mathrm{t}$ ), also, the exported volumes were under $1.0 \mathrm{t}$ in 2015 and 2017 with 0.6 and $0.2 \mathrm{t}$, respectively.

The Pearson's correlation coefficients are shown in Table 8 for: 1) Elastic behavior, which is shown in the upper line and is referred to: a) Export reference price and Exported volume (left-hand), and b) Export reference price and income (right-hand); 2) Inelastic behavior, which is shown in the bottom line, and is referred to: a) Export reference price and exported el menor en el año 2012 (-100,00\%). En el Cuadro 5 también se muestra la relación del valor exportado y el precio de referencia de exportación, ya que se puede observar que el volumen exportado fue variable. La mayor cantidad exportada se obtuvo en el año 2007 (253,6t) y la menor en el año 2011 (1.5 t), además, el volumen exportado fue bajo en 2014 (3,9 t). En relación al precio de referencia de exportación, fue más alto en el año 2011 (2.283,7 US $\$ /$ t) y más bajo en el año 2003 (604,2 US \$ / t). Además, el precio de referencia de exportación fue variable. Las exportaciones no se realizaron en los años 2012 y 2013.

\section{Calabaza}

La semilla para siembra de calabaza tuvo una demanda cambiante, ya que varió de 0,15 (el año 2007) a 12,65 (el año 2003). Hubo siete demandas inelásticas y 13 demandas elásticas. Esto significa que la demanda fue mayoritariamente elástica. En relación al aumento de ingresos, fue negativo en 11 años y positivo en nueve años. Los mayores aumentos de ingresos fueron 318,38\% en el año 2011 y los más bajos -84,94\% en el año 2002 (Cuadro 6).

En la Cuadro 6, también se muestra el valor exportado y el precio de referencia de exportación. Como se puede observar, el volumen de exportación fue mayor en el año 1999 con 588.6 t (el único caso cuando el volumen exportado superó las 500 t) y el menor ocurrió en el año 2002 con solo 43,6 t, pero la cantidad exportada del producto fue muy irregular a lo largo de los años. En relación con la exportación, el precio de referencia 


\section{Rev. Fac. Agron. (LUZ). 2021, 38(4): 1108-1133. Octubre-Diciembre.}

\section{Orozco et al.}

ISSN 2477-9407

volume (left-hand), and b) Export reference Price and income (right-hand). Both correlations correspond to all six Mexican seeds.

When the elasticity was elastic, the correlation between the ERP and $\mathrm{EV}$ was non significative $(\mathrm{p}>0.05)$, for yellow corn, sorghum, chickpea, and cucumber. The same behavior is observed in the correlation between ERP and Income. For pumpkin this only applies to the Export volume. However, regarding the other corn seeds, the correlation was positive and significant $(\mathrm{p} \leq 0.05)$, and highly significant $(p \leq 0.01)$ for EV and Income, respectively. This means that, when the ERP increases (decreases) the Income also increases (decreases), showing a directly proportional relation. These results suggest that, in this particular case, as the ERP increases Mexican exporters obtain more incomes from corn seed exportation, which is entirely profitable.

On the other hand, for pumpkin, the correlation between the ERP and Incomes was positive and significative $(p \leq 0.05)$. This is because an increase (decrease) in the ERP results also in an increase (decrease) of incomes, with a directly proportional relation.

For four seeds (yellow corn, sorghum, chickpea, and cucumber), a non-significant correlation $(\mathrm{p} \leq 0.05)$ was found. This indicates that when the ERP increases or decreases there is no defined trend with respect to the $\mathrm{EV}$ and Income.

When elasticity is inelastic, it is observed that there is no correlation ( $p>0.05)$ for sorghum, and cucumber, which means that there is no defined fue más alto durante 2011 con $6.736,8$ US \$ / t y más bajo durante 2003 con solo 1.097,8 US \$ / t. Además, el precio de referencia de exportación fue muy irregular a lo largo de los años, pero nunca disminuyó por debajo de los 1.000 US $\$ / \mathrm{t}$.

\section{Pepino}

La elasticidad precio de la demanda de semillas de pepino fue elástica durante 17 años e inelástica en tres años. Estos resultados mostraron que la elasticidad era principalmente elástica. La mayor elasticidad se obtuvo en el año 2003 con 14,74 y la menor en el año 2011 con 0,69. Por otro lado, hubo diez años en los que el aumento de los ingresos fue negativo y diez años en los que el aumento de los ingresos fue positivo. El mayor incremento de ingresos se obtuvo en el año 2012 con $272,99 \%$ y el menor en el año 2015 con -81,21\% (Cuadro 7).

En la Cuadro 7 se muestra la evolucion histórica del valor exportado y del precio de referencia de exportación, como se puede observar, el precio de referencia de exportación fue más alto en el año $2016(692,252.40$ US $\$ / \mathrm{t})$ y más bajo en el año 1998 (66,815.6 US \$ / t). En relación al volumen exportado, fue mayor en el año 1998 (14.2 t) y menor en el año 2016 (apenas 0.1 t), además, los volúmenes exportados estuvieron por debajo de $1.0 \mathrm{t}$ en 2015 y 2017 con 0.6 y $0.2 \mathrm{t}$, respectivamente.

La Cuadro 8, muestra los coeficientes de correlación de Pearson para: 1) Comportamiento elástico, el cual se muestra en la parte superior y alude a lo siguiente: a) Precio de exportación de referencia y Volumen 


\section{Rev. Fac. Agron. (LUZ). 2021, 38(4): 1108-1133. Octubre-Diciembre.}

\section{Orozco et al.}

trend between the ERP and Income. In the case of all corn seeds, and pumpkin, this observation only applies to the relation between the ERP and Income, which showed a positive and highly significative correlation $(\mathrm{p} \leq 0.01)$, showing a directly proportional relation. For sorghum, the correlation of ERP was positive and significant $(\mathrm{p} \leq 0.05)$, with respect to the EV. For chickpea, it was not possible to estimate de correlation coefficient for inelastic demand. This is because all other elasticities were inelastic. This suggests that, for these seeds exportations increase, resulting in a profitable situation for exporters.

The price elasticity of demand was mostly elastic for yellow corn (55.6\%), other corns, except yellow and sweet corns (60.0\%), chickpea (89.5\%), pumpkin (65.0\%) and cucumber (85.0\%) and was low in sorghum (46.2\%). Demand is elastic if the increase in the price reduces importer spending and if reducing it increases importer spending, demand is inelastic if increasing the price increases importer spending and if reducing it reduces spending of the importer and demand is unitary, when the price increases or decreases, importer spending remains constant.

In summary, the demand is elastic if the price varies, importer spending varies in the opposite direction; it is inelastic if, when the price varies, the cost of the importer varies in the same direction. In the inelastic demand, if the price is increased, demand remains stable, in contrast, in elastic demand; the price increases will cause many importers to stop purchasing the planting seeds as it is the case of all six planting seeds except sorghum. exportado (izquierda) así como b) Precio de exportación de referencia e ingresos (Derecha). También se muestra: 2) Comportamiento inelástico, el cual se muestra en la parte inferior y alude a lo siguiente a) Precio de exportación de referencia y Volumen exportado (izquierda) y b) Precio de exportación de referencia e ingresos (Derecha). Las dos correlaciones son referidas a las seis semillas de cultivo mexicanas.

Cuando la elasticidad fue elástica, se puede observar que hubo una correlación no significativa $(p>0,05)$ entre Precio de exportación de referencia y Volumen exportado, así como Precio de exportación de referencia e ingresos, para maíz amarillo, sorgo, garbanzo y pepino. En el caso de Calabaza solo aplica para el Volumen exportado. Sin embargo, la correlación para otros maíces fue positiva y significativa $(p \leq 0,05)$ y altamente significativa $(p \leq 0,01)$ para Volumen exportado e Ingresos, respectivamente. Esto significa que cuando el Precio de exportación de referencia aumenta o disminuye, también aumenta o disminuye el ingreso, siendo estos directamente proporcionales. Estos resultados sugieren que, para este caso en particular, cuando aumenta el precio de referencia de exportación, los exportadores mexicanos venden más semillas de maíz y obtienen más ingresos, situación muy rentable para ellos y viceversa.

Por otro lado, la correlación para calabaza fue positiva significativa ( $p$ $\leq 0,05)$ entre el Precio de exportación de referencia con relación al ingreso. 
Rev. Fac. Agron. (LUZ). 2021, 38(4): 1108-1133. Octubre-Diciembre.

Table 8. Pearson's correlation coefficients (r) between export reference price (ERP) with exported volume (EV) and income of six Mexican planting seeds exported to United States of America from Mexico in the period 1998-2018 when elasticity was elastic (above) and when elasticity was inelastic (below).

Cuadro 8. Coeficientes de correlación de Pearson (r) del precio de referencia de exportación (ERP) con el volumen exportado (EV) y el ingreso de seis semillas para las siembras mexicanas exportadas a Estados Unidos de América desde México, en el período 1998-2018 cuando la elasticidad era elástica (arriba) y cuando la elasticidad era inelástica (abajo).

\begin{tabular}{|c|c|c|c|c|c|c|}
\hline & Yellow corn & Other corn $\dagger$ & Sorghum & Chickpea & Pumpkin & Cucumber \\
\hline Yellow corn & $\begin{array}{c}-0.352 \& \\
0.115 \\
0.775 \& \\
0.999 * *\end{array}$ & & & & & \\
\hline Other conn & & $\begin{array}{c}0.693 * \& \\
0.808 * * \\
0.272 \& \\
0.913 * *\end{array}$ & & & & \\
\hline Sorghum & & & $\begin{array}{c}-0.414 \& \\
-0.309 \\
-0.999 * \& \\
0,631\end{array}$ & & & \\
\hline Chickpea & & & & $\begin{array}{c}-0.272 \& \\
0.394 \\
\mathrm{NE}\end{array}$ & & \\
\hline Pumpkin & & & & & $\begin{array}{c}0.229 \& \\
0.573^{*} \\
0.513 \& \\
0.980^{* *}\end{array}$ & \\
\hline Cucumber & & & & & & $\begin{array}{c}-0.161 \& \\
0.154 \\
-0.952 \& \\
-0037\end{array}$ \\
\hline
\end{tabular}

$* *$ Altamente significativo $(\mathrm{p} \leq 0.01) .{ }^{*}$ Significativo $(\mathrm{p} \leq 0.05)$. Los datos reportados $\sin (*, * *)$ son no significativos $(\mathrm{p}>0.05)$. $\dagger$ Los primeros valores son entre ERP y EV, mientras que los segundos entre ERP y las ganancias.

Nota: NE: No Estimado. El número de observaciones fueron 10, 12, 6, 17, 13 y 17 para el maíz Amarillo, otros tipos de maíz (except amarillo y dulce), sorgo, garbanzo, calabaza y pepino, respectivamente, para elasticidad elástica, y 4, 8, 3, 0,7 y 3, respectivamente, para elasticidad inelástica. El ingreso fue estimado como I = ERP $\times \mathrm{EV}$.

** Highly significant $(p \leq 0.01)$. * Significant $(p \leq 0.05) . r^{\prime}$ s without ** and * are not significant $(p>0.05)$. † First r's are between ERP and EV and second $r^{\prime}$ s are between ERP and income.

Note: NE: No estimated. Number of observations were 10, 12, 6, 17, 13 and 17 for yellow corn, other cons (except yellow and sweet corn), sorghum, chickpea, pumpkin and cucumber, respectively) when elasticity was elastic and 4, 8, 3, 0, 7 and 3 when elasticity was inelastic. Income was calculated as: I $=\mathrm{ERP} \times \mathrm{EV}$ 


\section{Rev. Fac. Agron. (LUZ). 2021, 38(4): 1108-1133. Octubre-Diciembre.}

\section{Orozco et al.}

The price elasticity of demand is a measure of how much the quantity demanded of planting seeds varies with variations in its price. The price elasticity of demand is the percentage of change in the quantity demanded given a percentage of change in the price. As it was mentioned before, the value of elasticity allows planting seeds to be classified according to their sensitivity to price variations. Three types of demand were distinguished according to this value: elastic demand that is the variation in the quantity demanded is a percentage higher than the price. Inelastic demand is the variation of the quantity demanded is a percentage lower than that of the price and unitary elasticity demand that is the variation of the quantity demanded is percentage equal to that of the price.

Another very important aspect is that referring to substitute products, since if there are numerous substitutes, the demand for the planting seeds will be elastic (yellow corn, other corns (except yellow and sweet corns, chickpea, pumpkin, and cucumber) and its consumption can be replaced. In the opposite case, with few substitutes, the demand will tend to be inelastic (sorghum); however, it is not possible to establish the causality of the results obtained in this investigation.

Similar results were reported by Vukadinović et al. (2017) who stated that the analysis of the demand elasticity coefficients shows that elasticity of demand is more dominant in comparison to the inelasticity. However, if one takes into account
Esto significa que cuando el Precio de exportación de referencia aumenta o disminuye, también aumenta o disminuye el ingreso, siendo directamente proporcionales.

Para las otras cuatro semillas (maíz amarillo, Sorgo, Garbanzo y Pepino), no se encontró correlación significativa $(p \leq 0.05)$, indicando que cuando el Precio de exportación de referencia aumenta o disminuye no se observa una tendencia definida con relación a Volumen exportado e Ingresos.

Table 8. Pearson's correlation coefficients (r) between export reference price (ERP) with exported volume (EV) and income of six Mexican planting seeds exported to United States of America from Mexico in the period 1998-2018 when elasticity was elastic (above) and when elasticity was inelastic (below).

Cuadro 8. Coeficientes de correlación de Pearson (r) del precio de referencia de exportación (ERP) con el volumen exportado (EV) y el ingreso de seis semillas para las siembras mexicanas exportadas a Estados Unidos de América desde México, en el período 1998-2018 cuando la elasticidad era elástica (arriba) y cuando la elasticidad era inelástica (abajo).

Cuandola elasticidad fueinelástica, se pudo observar que no hubo una Correlación significativa $(\mathrm{p}>0,05)$, para Sorgo, y Pepino, esto significa que cuando el Precio de exportación de referencia aumenta o disminuye no se observa una tendencia definida con relación al Ingreso. En el caso de Maíz amarillo, otros Maíces, y Calabaza solo 


\section{Rev. Fac. Agron. (LUZ). 2021, 38(4): 1108-1133. Octubre-Diciembre.}

\section{Orozco et al.}

the indifference of the elasticity of demand, then the situation changes and it becomes evident that the elasticity of demand does not dominate the planting seed of sorghum to less extent for yellow corn.

The largest numbers of indifferent positions in the categories of planting seeds were observed for sorghum and yellow corn. This situation reflects the fact that in these planting seeds there is the largest number of positions in which demand is not dependent on changes in prices and that the indifference was affected by other factors of demand that are of nonprice character. The highest elasticity coefficient calculated in the planting seed crops was 83.24 for chickpea, which means that in $2002,1 \%$ of changes in prices parked $83.24 \%$ of changes in the quantity demanded of chickpea planting seeds. The minimum coefficient of elasticity was calculated in other corn (except yellow and sweet corn) and it was 1.03 , which means that in $2015,1 \%$ of price changes caused $1.03 \%$ of changes in the quantity demanded of other corn planting seeds. This coefficient almost brings closer the elasticity of demand to unit elasticity.

The highest coefficient of inelasticity calculated in yellow corn and pumpkin planting seeds was 0.94 , which means that price changes $1 \%$ in 2004 and 2005, respectively caused a change in the quantity demanded of products by $0.94 \%$. The lowest coefficient of inelasticity was calculated in yellow corn and other corns (except yellow corn and sweet corn) and was 0.07 , which means aplica para el Precio de exportación de referencia e Ingresos y esta fue positiva y altamente significativa ( $p$ $\leq 0,01$ ), esto significa que cuando el Precio de exportación de referencia aumenta o disminuye, también aumenta o disminuye el ingreso, siendo directamente proporcionales. Para el caso de Sorgo la Correlación fue positiva y significativa $(\mathrm{p} \leq 0,05)$ entre el Precio de exportación de referencia y Volumen exportado.

Para el garbanzo no fue posible calcular el coeficiente de correlación cuando la demanda era inelástica porque todas las elasticidades eran elásticas.

Estos resultados sugieren que, para maíz amarillo, otros maíces y semillas de calabaza, cuando el precio de referencia de exportación aumenta, los exportadores mexicanos venden más de estas semillas de siembra y exportan más productos, de nuevo es una situación muy rentable para ellos.

La elasticidad precio de la demanda fue mayoritariamente elástica para maíz amarillo (55,6\%), otros maíces, excepto maíz amarillo $y$ dulce $(60,0 \%)$, garbanzo $(89,5 \%)$, calabaza $(65,0 \%)$ y pepino $(85,0 \%)$ y fue baja en sorgo (46,2\%). La demanda es elástica si el aumento del precio reduce el gasto del importador y si al reducirlo aumenta el gasto del importador, la demanda es inelástica si el aumento del precio aumenta el gasto del importador y si la reducción reduce el gasto del importador y la demanda es unitaria, cuando el precio aumenta o disminuye, el gasto de los importadores se mantiene constante. 
Rev. Fac. Agron. (LUZ). 2021, 38(4): 1108-1133. Octubre-Diciembre.

Orozco et al.

ISSN 2477-9407

that $1 \%$ of the change in 2017 and 2004, respectively, in prices of these planting seeds caused only $0.007 \%$ of the product quantities changes. This coefficient brings closer the elasticity of demand in these products to the perfectly inelastic demand.

\section{Conclusions}

The results presented in this research allow us to conclude that 5 from 6 planting seeds showed a PED relatively elastic during most part of the years under investigation. Theoretically, this implies that the effect of the exported quantity was predominant with respect to the effect of the price. According to this, we would expect that during those years the incomes raise when prices lowered; on the contrary, the behavior of incomes showed positive and negative values, with no defined trends. For the sixth seed (sorghum), the demand was elastic in some cases and inelastic in many others. The behavior of incomes also showed an undefined trend for each of these cases.

The presence of no trends is complementary with the values of Pearson correlations: these show no significant levels between prices and incomes for each PED. For practical implications of these findings, the impact of PED on the incomes cannot be predicted with accuracy. Finally, our results depart from the classical theory of PED, since there is no defined trend in the incomes, with respect to variations in price for each detected elasticity. More work is required to investigate the causality of these results.
En resumen, la demanda es elástica si el precio varía, el gasto de los importadores varía en la dirección opuesta; es inelástica si, cuando varía el precio, el costo del importador varía en la misma dirección. En la demanda inelástica, si se incrementa el precio, la demanda permanece estable, en contraste, en la demanda elástica; los aumentos de precios harán que muchos importadores dejen de comprar las semillas de siembra como es el caso de las seis semillas de cultivo excepto el sorgo.

La elasticidad precio de la demanda es una medida de cuánto varía la cantidad demandada de semillas con las variaciones de su precio. La elasticidad precio de la demanda es el porcentaje de cambio en la cantidad demandada dado un porcentaje de cambio en el precio. Como se mencionó anteriormente, el valor de la elasticidad permite clasificar las semillas de cultivo según su sensibilidad a las variaciones de precio. Se distinguieron tres tipos de demanda según este valor: demanda elástica que es la variación en la cantidad demandada es un porcentaje superior al precio. La demanda inelástica es la variación de la cantidad demandada es un porcentaje menor que la del precio y la demanda de elasticidad unitaria es la variación de la cantidad demandada es un porcentaje igual a la del precio.

Otro aspecto muy importante es el referido a los productos sustitutos, ya que, si existen numerosos sustitutos, la demanda de las semillas de siembra será elástica (maíz amarillo, otros maíces excepto maíz amarillo 


\section{Rev. Fac. Agron. (LUZ). 2021, 38(4): 1108-1133. Octubre-Diciembre.}

\section{Orozco et al.}

\section{Acknowledgement}

The authors thank the University of Guanajuato for promoting scientific research as a strategic pillar to strengthen teaching.

\section{End of English Version}

dulce, garbanzo, calabaza y pepino) y su consumo. En el caso contrario, con pocos sustitutos, la demanda tenderá a ser inelástica (sorgo), sin embargo, no es posible establecer la causalidad de los resultados obtenidos en esta investigación.

Resultados similares fueron reportados por Vukadinović et al. (2017) quienes afirmaron que el análisis de los coeficientes de elasticidad de la demanda muestra que la elasticidad de la demanda es más dominante en comparación con la inelasticidad. Sin embargo, si se tiene en cuenta la indiferencia de la elasticidad de la demanda, entonces la situación cambia y se hace evidente que la elasticidad de la demanda no domina para la semilla de sorgo y en menor medida para el maíz amarillo.

Se observó el mayor número de posiciones indiferentes en las categorías de semillas de siembra para sorgo y maíz amarillo. Esta situación refleja el hecho de que para estas semillas existe el mayor número de posiciones en las que la demanda no depende de cambios en los precios y que la indiferencia se vio afectada por otros factores de demanda que son de carácter no atinentes al precio. El coeficiente de elasticidad más alto calculado para las semillas de cultivo fue de 83,24 para el garbanzo, lo que significa que en 2002 el 1\% de los cambios en los precios occasionó el $83,24 \%$ de los cambios en la cantidad demandada de semillas de garbanzo para la siembra. El coeficiente mínimo de elasticidad se calculó en otros maíces (excepto maíz amarillo y dulce) y fue de 1.03, lo que significa que, en 2015, 1\% de los cambios de precios ocasionaron $1.03 \%$ de cambios en la cantidad demandada de otras semillas de siembra de maíz. Este coeficiente casi acerca la elasticidad de la demanda a la elasticidad unitaria.

El mayor coeficiente de inelasticidad calculado en semillas de maíz amarillo y calabaza para la siembra fue de 0,94 , lo que significa que los cambios de precio de $1 \%$ en 2004 y 2005, respectivamente, provocaron un cambio en la cantidad demandada de productos en $0,94 \%$. El menor coeficiente de inelasticidad se calculó en maíz amarillo y otros maíces (excepto maíz amarillo y maíz dulce) y fue de 0,07 , lo que significa que el 1\% del cambio en 2017 y 2004 , respectivamente, en los precios de estas semillas para siembra causó solo $0,007 \%$ de cambio en las cantidades de producto. Este coeficiente acerca la elasticidad de la demanda de estos productos a la demanda perfectamente inelástica.

\section{Conclusiones}

Los resultados presentados en esta investigación permiten concluir que 5 de 6 semillas para siembra (maíz, otros maíces excepto maíz amarillo y dulce, garbanzo, calabaza y pepino) 
Rev. Fac. Agron. (LUZ). 2021, 38(4): 1108-1133. Octubre-Diciembre.

Orozco et al.

ISSN 2477-9407

mostraron una EPD relativamente elástica durante la mayor parte de los años bajo investigación. En teoría, esto implica que el efecto de las cantidades exportadas fue predominante con respecto al efecto del precio. De acuerdo con esto, se esperaria que, durante esos años, los ingresos suban cuando bajan los precios; por el contrario, el comportamiento de los ingresos mostró valores positivos y negativos, sin tendencias definidas. Para la sexta semilla (sorgo), la demanda fue elástica en algunos casos e inelástica en muchos otros. El comportamiento de los ingresos también mostró una tendencia indefinida para cada uno de estos casos.

La ausencia de tendencias es complementaria con los valores de las correlaciones de Pearson: estas no muestran niveles significativos entre precios e ingresos para cada EPD. Para las implicaciones prácticas de estos hallazgos, el impacto de la EPD en los ingresos no se puede predecir con precisión. Finalmente, nuestros resultados se apartan de la teoría clásica de la EPD, ya que no existe una tendencia definida en los ingresos, con respecto a las variaciones de precio para cada elasticidad detectada. Se requiere más trabajo para investigar la causalidad de estos resultados.

\section{Agradecimiento}

Los autores agradecen a la Universidad de Guanajuato por impulsar la investigación científica como pilar estratégico para fortalecer la docencia.

\section{Literature cited}

Centro de Estudios para el Desarrollo Rural Sustentable y la Soberanía Alimentaria. 2015. Las semillas en México. Reporte del CEDRSSAR. https://cutt.ly/pnimDoD

De la Fuente Traverso, T. 2014. Una mirada a la industria semillera. https://cutt. ly/TnimHHU

Foreign Agriculture Service. 2019. Global agriculture trade system online. United States Department of Agriculture. https://cutt.ly/znimKPN

Herrera B., V. H. 2013. Análisis de la demanda de tabaco en Panamá y el control del efecto asequibilidad con medidas fiscales y control del contrabando: Implicaciones para Política Fiscal 2000-2011. https://cutt. ly/wnimLBZ

Hernández Díaz, A. G. and E. C. García Cobián. 2014. Elasticidad precio de la demanda y perfil de los usuarios de la parada "Pablo de Olavide" de Metro de Sevilla. Revista de Métodos Cuantitativos para la Economía y la Empresa, (17): 80-100. https://cutt.ly/ OnimNVj

International Seed Federation. 2018a Exports of seed for sowing by country - Calendar year 2017. https://cutt.ly/ Mnim1qk

International Seed Federation. 2018b. Imports of seed for sowing by country - Calendar year 2017. https://cutt.ly/ pnim0o2

Krugman, P. and R. Wells. 2006. Introducción a la microeconomía. Editorial Reverte.

Licona Michel, A. and G. Correa López, 2020. Comercio y distribución de la inversión extranjera directa de Estados Unidos de América en los Estados Unidos Mexicanos. Cimexus, 15(1): 33-56. https://cutt.ly/lngiKCn

Luna Mena, B. M., M. A. Hinojosa Rodríguez, O. J. Ayala Garay, F. Castillo González and A. Mejía Contreras. 2012. Perspectivas de desarrollo de 
Rev. Fac. Agron. (LUZ). 2021, 38(4): 1108-1133. Octubre-Diciembre.

\section{Orozco et al.}

la industria semillera de maíz en México. Revista Fitotecnia Mexicana, 35(1): 1-7. https://cutt.ly/Enim271

MasterIT.ie. 2006. Arc elasticity calculator. Computer Consultancy, Website Development, Educational Software. https://cutt.ly/fnim8Vh

Mastretta-Yanes, A., M. R. Bellon, F. Acevedo, C. Burgeff, D. Piñero and J. Sarukhán. 2019. Un programa para México de conservación y uso de la diversidad genética de las plantas domesticadas y sus parientes silvestres. Rev. Fitotec. Mex. 42(4): 321-334. https://cutt.ly/lngiMQy

Miller, R. L. and R. E. Meiners. 1990. Microeconomía. McGraw-Hill. México.

Mora Rivera, J., A. Zamudio Carrillo, H. Fuentes Castro. 2014. Volatilidad e interdependencia en los precios agrícolas a partir de un modelo GARCH multivariado. Anal. Econ. XXIX (72): 35-56. https://cutt.ly/ $\operatorname{Inim} 7 \mathrm{zi}$
Omni-Calculator. 2019. Price Elasticity of Demand Calculator. https://cutt.ly/ Nnim6aZ

Gobierno del Estado de Jalisco. 2015. Jalisco, líder en exportación de semillas con alta calidad genética. https://cutt.ly/ kniQqQ9

Samuelson, P. A., and W. D. Nordhaus. 2005. Economia. McGraw - Hill Interamericana.

Suárez Lugo, N. 2017. Consumo de cigarrillos y elasticidad precio-demanda. Horiz. sanitario (en linea). 16 (3): 163-174. http://dx.doi.org/10.19136/ hs.a16n3.1751

Vukadinović, P., A. Damnjanović and J. Krstić-Ranđić. 2017. The analysis of indifference and the price elasticity of demand between different categories of agricultural products. Economics of Agriculture, 64 (2): 671-685. https:// doi.org/10.5937/ekoPolj1702671V 